\title{
Responsible Leadership as Virtuous Leadership
}

\author{
Kim Cameron
}

Received: 28 April 2011/Accepted: 15 June 2011/Published online: 27 September 2011

(C) The Author(s) 2011. This article is published with open access at Springerlink.com

\begin{abstract}
Responsible leadership is rare. It is not that most leaders are irresponsible, but responsibility in leadership is frequently defined so that an important connotation of responsible leadership is ignored. This article equates responsible leadership with virtuousness. Using this connotation implies that responsible leadership is based on three assumptions-eudaemonism, inherent value, and amplification. Secondarily, this connotation produces two important outcomes-a fixed point for coping with change, and benefits for constituencies who may never be affected otherwise. The meaning and advantages of responsible leadership as virtuous leadership are discussed.
\end{abstract}

Keywords Virtuousness - Leadership - Responsible leadership · Virtuous leadership · Ethics · Virtues

Responsible leadership is rare. It is not that most leaders are irresponsible, but responsibility in leadership is frequently defined so that an important connotation of responsible leadership is ignored. The objective of this article is to highlight this oft-ignored attribute of responsible leadership, review its meaning, and identify two advantages it serves for organizations.

K. Cameron $(\bowtie)$

Ross School of Business, University of Michigan, Ann Arbor, MI 48108, USA

e-mail: kim_cameron@umich.edu
The idea that organizations need responsible leaders is quite common. In political elections, voters try to determine which candidate will actually follow-through on campaign promises, and in business organizations, boards of directors seek to select CEOs whom they estimate to be most responsible for the organization's performance and capital. The literature on effective leadership has largely included an element of responsibility (Doh and Stumph 2005; Yukl et al. 2002). Responsibility in this sense most often is synonymous with accountability and dependability (as in being accountable for performance and being dependable in achieving promised performance) (Bass and Bass 2008; Meindl and Ehrlich 1987).

Responsibility is also commonly associated with freedom of action and empowerment, indicating that responsible individuals have discretion or volition and the necessary authority. They have the wherewithal and the resources to achieve an objective (as in having responsibility at work, or being given the responsibility for an activity or outcome) (Spreitzer 2007). These two connotations of leadership responsibility are closely related, as leaders are more likely to be accountable and dependable if they are able to act freely and to feel empowered to perform (Spreitzer et al. 1999; Salancik and Meindl 1984). In these two senses, responsibility means "response-able," or possessing the capability and the capacity needed to respond.

A third connotation of responsible leadership has been proposed by Pless and colleagues in which responsible leaders are described as possessing certain characteristics and performing particular roles. Responsible leadership in these discussions is grounded in stakeholder theory-that is, leaders interact with and have responsibility for multiple stakeholders. The roles associated with responsible leadership include "architect, change agent, citizen, coach, 
networker, servant, storyteller, steward, and visionary" (Maak and Pless 2006b, p. 107; Pless 2007, p. 439), and the characteristics of responsible leaders are quite extensive. ${ }^{1}$ Responsible leadership in these discussions is defined in this way: "Responsible leadership can be understood as the art of building and sustaining social and moral relationships between business leaders and different stakeholders (followers), based on a sense of justice, a sense of recognition, a sense of care, and a sense of accountability for a wide range of economic, ecological, social, political, and human responsibilities" (2007, p. 451). The multiple roles, characteristics, and relationships advocated are inclusive of most of the major theories of leadership (e.g., transformational, charismatic, servant, and ethical) and place responsible leadership as an encompassing ideal type.

A fourth connotation of the concept of responsible leadership is less frequently used but equally meaningful. It is the attribute that makes a certain type of responsible leadership rare. It refers to the ability or inclination to act in an appropriate fashion (as when an individual acts responsibly). The concept of appropriateness is key to this connotation in that it associates responsible action with what is right, correct, or best. Behaving responsibly in this sense means being good or doing good (Walsh et al. 2003). Of course, what is considered good is often controversial, ${ }^{2}$ but one term that connotes universal standards of rightness,

\footnotetext{
$\overline{1}$ Responsible leadership characteristics are reported to include "building public trust," "sustaining an impeccable reputation," "walking the talk," "managing with integrity," "making profits with principles," "delivering on the triple bottom line," "creating value for stakeholders," "mobilizing people and teams," "coaching and reinforcing employees," "creating incentives to encourage respectful collaboration," "safeguarding freedom of speech," "ensuring adherence to employment standards," "proving fair and equal employment opportunities," "making sure that products and services meet customer needs," "ensuring that ethical standards are respected," "driven by a values-based vision of the future," "having a fundamental values base," "maintaining personal and professional integrity," "making principled decisions," "using values as a moral compass," "promoting active citizenship inside and outside the organization," "being rooted in an ethics of care," "being driven by a desire to serve others," "humility and modesty," "an inclination to support others and to care for their interests and needs," "being connected and close to stakeholders," "growing and sustaining a web of stakeholder connections," "having a drive to realize the vision in and through stakeholder engagement," "being cooperative," "being inclusive," "being empathetic," "creating a values-based sense of identify among stakeholders," "a combination of cognitive, emotional, relational, and moral qualities," and other characteristics (see Maak and Pless 2006a, b; Pless 2007).

2 This connotation of responsible leadership, of course, raises the issue of what is meant by right, correct, beneficial, or good. The problem, of course, is that some argue that what may be right or good for one may not be good for another, or what is beneficial for some may not be beneficial for all (Fineman 2006). This article does not propose to review these various arguments but, rather, to suggest that virtuousness can serve as one universalistic standard for what is defined as right, correct, or good.
}

correctness, and goodness is the concept of virtuousness (Cameron and Winn 2012; Cameron et al. 2011). This concept is a universally accepted standard for the best of the human condition (Comte-Sponville 2001; Dutton and Sonenshein 2007; Peterson and Seligman 2004). Using this connotation, responsible leadership is equated with virtuous leadership, or leadership oriented toward being and doing good.

Responsibility used in the first three ways is associated with achieving desired instrumental results, such as productivity, customer retention, sustainability, morale, effective networks, or employee well-being. Used in the fourth way, responsibility is associated with promoting goodness for its own sake (Cameron et al. 2003). It focuses on the highest potentiality of human systems, or on virtuousness.

\section{The Meaning of Virtuousness in Leadership}

Virtuousness is not a common term in scientific circles. The prevailing tradition in organizational studies suggests that discussions of virtuousness are associated with social conservatism, religious dogmatism, and scientific irrelevance (Chapman and Galston 1992; MacIntyre 1984; Schimmel 1997). Virtuousness is often relegated to theology, philosophy, or mere naiveté. Fowers (2008), for example, accused positive psychologists of being "superficial" and "colloquial" in their understanding of virtue. Fineman (2006) argued that virtuousness is culturally restrictive and narrow-minded. Its relevance in the world of work and in organizations has little credence in the face of economic pressures and stakeholder demands. Confirming this bias, Walsh (1999) analyzed word usage in the Wall Street Journal from 1984 through 2000 and reported that the appearance of terms, such as "win," "advantage," and "beat," had risen more than fourfold over that 17-year period in reference to business organizations. Terms, such as "virtue," "caring," and "compassion," on the other hand, seldom appeared at all in reference to business. The use of these terms remained negligible across the same 17-year period of time.

A review of scholarly literature relating to the concept of virtuousness (including the terms "virtues," "civic virtues," "moral virtues," and "virtue ethics") reveals that little agreement exists regarding its definition and attributes (Cameron and Winn 2012). Most articles focus on the debate about whether or not virtuousness actually exists (Alzola 2008; Wright and Goodstein 2007; Weaver 2006; Whetstone 2003), on the development of virtue in societies (Moore and Beadle 2006; Nielsen 2006), or on the definition of the term (Fowers 2009; Moberg 1999; Rachels 1999). A few articles have attempted to identify universal 
attributes of virtuousness or to develop instruments to measure them (Chun 2005; Peterson and Seligman 2004; Shanahan and Hyman 2003), but two striking features characterize this literature. First, virtuousness is seldom associated with leadership and almost never with organizations. Second, very few studies have been conducted in which virtuousness is investigated empirically (Rego et al. 2010; Den Hartog and De Hoogh 2009; Bright et al. 2006; Sison 2006; Caza et al. 2004; Cameron et al. 2004).

\section{Virtue Versus Virtuousness}

The term virtue refers to singular attributes that represent moral excellence. Based on the Latin word virtus, or the Greek arête, a virtue is not a product of social convention but is a basic element of the human condition (Rachels 1999). Aristotle (1999) equated it with "excellence in the human soul." Virtue is sometimes equated with character strengths (Grant and Schwartz 2011; Peterson and Seligman 2004), but virtue and character strengths are not synonymous. One can possess too much or too little of a strength, and in doing so it may become a weakness or produce a negative outcome (as when too much tolerance becomes spinelessness and too little tolerance becomes bigotry). Virtuousness, on the other hand, cannot be exceeded.

Virtuousness also differs from the concept of ethics. A dominant (although not exclusive) emphasis in the leadership ethics literature is on avoiding harm, fulfilling contracts, ensuring compliance, and obeying rules and laws (Brown and Trevino 2006; Handelsman et al. 2002; Trevino et al. 2003). In practice, ethics are understood and implemented as duties (Rawls 1971). They are usually specifications designed to prevent damage or avoid injury (Orlikowski 2000), or to ensure compliance (Brown and Trevino 2006). Unethical action is harmful, detrimental, or destructive, and so to behave ethically is to avoid doing harm, damaging another individual, or destroying something valuable. Admittedly, a few authors (e.g., Maak and Pless 2006b; Sison 2006; Pless 2007) have included virtuousness as one of the attributes of responsible leadership, but the comprehensiveness of the characteristics incorporated and its association with instrumental outcomes differentiate it from virtuous leadership as discussed in the fourth connotation.

In contrast to the dominant approach to ethics, virtuousness possesses an affirmative bias and focuses on elevating, flourishing, and enriching outcomes. Virtuousness pursues the ultimate best-eudaemonism-rather than merely avoiding the negative or emphasizing the attainment of more valuable outcomes. More importantly, unlike ethics—which may be situational—virtuousness represents a universal and stable standard of the good (Cameron 2006).
Aquinas (1984) proposed that virtuousness is rooted in human character and represents "what human beings ought to be," inherent goodness, humanity's very best qualities, or being in complete harmony with the will of God (also, Aristotle, Metaphysics XII; Sison 2006). Virtuousness refers to a constellation of virtues in the aggregate. Just as individuals may possess more than one virtue, responsible leadership in organizations also may display and enable more than one virtue. Responsible leadership as equated with virtuousness, then, is leadership that exemplifies a combination of virtues. From the organization level of analysis, virtuousness may be fostered by the organizational policies, processes, practices, and culture nurtured by leaders (Cameron 2010; Dutton and Sonenshein 2007).

\section{Examples}

Examples of virtuous leadership might be illustrated by the senior leaders at Prudential's Relocation Company contacting senior executives at BP Oil Company shortly after the Gulf of Mexico oil spill. They offered to provide free relocation services from the UK to the U.S. until the spill was cleaned-up. The rationale: "We want to help, and we think that this is just the right thing to do" (personal communication). Or, the approach to cost cutting and downsizing at Griffin Hospital in which a culture characterized by "compassion, highest levels of integrity, forgiveness, and love" was developed by the senior leaders as a result of the announced downsizing activities (Cameron 2008). Or, the Rocky Flats Nuclear Arsenal case in which leadership honesty, virtuousness, and personal concern were keys to an extraordinary, almost unbelievably rapid and effective clean-up and closure of North America's most dangerous location (Cameron and Lavine 2006).

\section{Attributes of Virtuousness}

Confusion regarding the meaning of virtuousness has been an important inhibitor to its use in organizational and leadership research. For example, virtuousness has been used interchangeably in the organization studies literature with corporate social responsibility (CSR), citizenship behavior, business ethics, justice, and strengths. Illustrations of the variety of definitions include Moberg's (1999) equating virtuousness with some of the Big Five personality attributes-namely, agreeableness and conscientiousness of managers in organizations-or Ewin's (1995) proposal that virtuousness is exemplified by the persuasive ability and influence techniques of salespersons. Sison (2006) associated virtuousness with the content of speech (logos), character traits (ethos), and emotional disposition (pathos) in the service of persuasion and governance, and Fowers $(2005,2009)$ equated virtuousness with ethics and 
with personal strengths in the pursuit of that which leads to beneficial instrumental outcomes, implying a hedonistic pursuit of human fulfillment.

Rather than being an instrumentally motivated action or emotion valued only because of what it produces, however, virtuousness as associated with responsible leadership refers to the most ennobling behaviors and outcomes, the excellence and essence of humankind, the best of the human condition, and the highest aspirations of humanity (Comte-Sponville 2001; Weiner 1993; Chapman and Galston 1992; Dent 1984; MacIntyre 1984). That is, virtuousness in leadership is less a means to another more desirable outcome than an ultimate good itself. This is important because some authors have criticized the current literature on virtuousness, ethics, and positivity as being co-opted by a market-based, profit-as-the-summonbonum ethic (Caza and Carroll 2012). They claim that if virtuousness is relevant only to gain a desired end (e.g., fulfilling customer demands), it is akin to manipulation and cooptation by the powerful at the expense of the less powerful.

Virtuous leadership does not assume, however, that profitability, customer service, or shareholder value are the ultimate ends. Responsible leadership using the fourth connotation does not assume that more suitable outcomes are needed in order for virtuous action or virtuous decisions to be taken. Rather, responsible leadership in this sense is characterized by three core assumptions-a eudaemonic assumption, an inherent value assumption, and an amplification assumption (Bright et al. 2006; Cameron and Winn 2012).

\section{The Eudaemonic Assumption}

Virtuousness is synonymous with the eudaemonic assumption. This is the assumption that an inclination exists in all human beings toward moral goodness (Aristotle, Metaphysics; Dutton and Sonenshein 2007). Several authors have provided evidence that the human inclination toward virtuousness is inherent and evolutionarily developed (Tangney et al. 2007; Miller 2007). Inherent virtuousness, or an inclination toward the best of the human condition, develops in the brain before the development of language. Studies of the human brain indicate that individuals appear to have a basic instinct toward morality and are organically inclined to be virtuous (Haight 2006; Hauser 2006; Pinker 1997). Krebs (1987, p. 113) asserted that human beings are "genetically disposed" to acts of virtuousness, and observing and experiencing virtuousness helps unlock the human predisposition toward behaving in ways that benefit others.

In functional terms, virtuousness is claimed to be evolutionarily developed because it allows people to live together, pursue collective ends, and protect against those who endanger the social order. From a genetic or biological perspective, virtuousness plays a role in the development and perpetuation of humanity. This also explains why virtuousness is highly prized and admired, and why virtuous individuals are almost universally revered, emulated, and even sainted. They help perpetuate the human species (Cameron and Winn 2012). Miller (2007) pointed out, for example, that a selective genetic bias for human moral virtuousness exists. He argued that mate selection evolved at least partly on the basis of displays of virtuousness.

\section{Inherent Value Assumption}

A second core assumption of virtuousness is that it represents "goods of first intent" (Aristotle 1999, p. 3), meaning that it represents inherent value. Virtuousness in leadership is not a means to obtain another end, but it is considered to be an end in itself. In fact, virtuousness in pursuit of another more attractive outcome ceases by definition to be virtuousness. Forgiveness, compassion, and courage in search of recompense are not virtuous. If kindness toward employees is demonstrated in an organization, for example, solely to obtain a payback or an advantage (kindness is displayed only if people work harder), it ceases to be kindness and is, instead, manipulation. Virtuousness is associated with social betterment, but this betterment extends beyond mere self-interested benefit. Virtuousness creates social value that transcends the instrumental desires of the actor(s) (Aristotle, Metaphysics VII). Virtuous leadership produces advantages to others in addition to, or even exclusive of, recognition, benefit, or advantage to the actor or the organization (Cawley et al. 2000).

This also explains why leadership virtuousness is different than participation in normatively prescribed CSR, sponsoring environmentally friendly programs, or utilizing renewable resources (Bollier 1996; Hoffman and Haigh 2012). Although some activities included in the CSR and corporate citizenship domains may represent virtuousness, these activities are typically explained as motivated by instrumental benefit or exchange relationships. That is, engagement in these actions is initiated to acquire benefit to the firm or advantages from a reciprocal arrangement (Batson et al. 1995; Fry et al. 1982; Moore and Richardson 1988; Piliavin and Charng 1990; Sánchez 2000). Exchange, reciprocity, and self-serving motives, however, are not indicative of virtuousness. Barge and Oliver (2003) and Gergen (1999) argued that associating an instrumental motive with organizational virtuousness changes the nature of the relationships among organization members and causes the behavior to evolve into "another technique of manipulation and discipline" (Barge and Oliver 2003, p. 11). Of course, virtuousness does not stand in opposition 
to concepts such as citizenship, social responsibility, or ethics, but it extends beyond them.

\section{Amplification Assumption}

A third assumption is that virtuousness creates and fosters sustainable positive energy. It is elevating and self-perpetuating, and it requires no external motivator for its pursuit. Because it is an ultimate end and an inherent attribute of human beings, virtuousness produces an elevating effect. This is to say, virtuousness is amplifying when it is experienced (George 1995). Observing virtuous leadership creates a self-reinforcing inclination toward more of the same. One difference between Aristotle's "goods of first intent" and "goods of second intent" is that people never tire of or become satiated with goods of first intent. Leaders cannot be too virtuous.

Fredrickson and Joiner (2002) found evidence that observing virtuousness in leaders creates upward spirals of positive dynamics. Compassion begets gratitude, gratitude motivates improved relationships, witnessing good deeds leads to elevation, elevation motivates prosocial behavior, and observing virtuousness fosters even more virtuousness (also see Algoe and Haight 2009; Maslow 1971; Hatch 1999; Sethi and Nicholson 2001). Studies reported by Cialdini (2000) and Asche (1952) support the idea that when people observe exemplary or virtuous behavior, their inclination is to follow suit. Fredrickson (2003) applied her "broaden and build" theory-explaining the effects of experiencing positive emotions-to virtuous leadership. Employees' and organizations' social, intellectual, and emotional capacities were expanded and increased as a result of experiencing and observing virtuousness (Fredrickson 2009).

This amplifying quality of virtuousness can be explained by its association with the heliotropic effect. The heliotropic effect is the attraction of all living systems toward positive energy and away from negative energy, or toward that which is life-giving and away from that which is lifedepleting (Smith and Baker 1960; D'Amato and Jagoda 1962; Mrosovsky and Kingsmill 1985). In nature, this is exemplified by light from the sun. Several researchers have described the dynamics of individuals and groups that experience virtuousness (e.g., Cameron 2008; Eisenberg 1986; Hatch 1999; Leavitt 1996; Sethi and Nicholson 2001) proposing that under such conditions, individuals experience a compelling urge to build upon the contributions of others and to perpetuate a virtuous spiral (Fredrickson 2003, 2009; Erhard-Seibold 1937; Dutton and Heaphy 2003). Observing virtuousness creates a self-reinforcing cycle toward more virtuousness.

In sum, one infrequently acknowledged connotation of responsibility in leadership is its association with virtuousness. Because virtuousness is a universal standard for the best of the human condition, it addresses the question: What is the most responsible approach to leadership? Being clear about what is meant by the term virtuousness is a prerequisite to addressing this question. Responsible leadership, of course, refers not only to the actions of leaders but also to the processes, strategies, and culture that they foster and enable which support and manifest collective virtuous behavior. That is, leaders behave in ways, and help foster organizational attributes, that are consistent with the highest aspirations of human kind. They enable and perpetuate virtuousness so that its self-perpetuating and amplifying effects are experienced by members of the organization in which they interact (Maak and Pless 2006b; Pless 2007).

\section{Benefits of Virtuous Leadership}

Accepting virtuousness as a key attribute of responsible leadership provides at least two functional benefits. While supplemental advantage is not needed for virtuous leadership to be valued, benefits do accrue nevertheless. One benefit is the role virtuousness plays in creating a fixed point in decision making. Another benefit is the increases in performance that virtuousness produces in organizations.

\section{Virtuousness as a Fixed Point}

It is commonly acknowledged that the most dominant feature of the current environment for organizations is turbulence. Change is generally acknowledged as ubiquitous and constant. Unfortunately, when everything is changing, it becomes impossible to manage change (Cameron 2006). Without a stable, unchanging reference point, direction and progress become indeterminate. Airplane piloting offers an instructive metaphor. The key to successful flight is adjusting the plane's movement in relation to a stable, unchanging referent such as land or the horizon. Without a fixed referent, it is impossible to steer a course. Pilots with no visual or instrumentation contact with a fixed point are unable to navigate.

Consider the last flight of John Kennedy, Jr., who began a flight up the New England coast at dusk. He lost sight of land and, when it grew dark, the horizon line as well. He lost his fixed point of reference. The result was disorientation, and he flew his plane into the ocean, likely without even knowing he was headed toward the water. He was unable to manage the continuously changing position of his airplane without a standard that remained unchanged.

The same disorientation afflicts individuals and organizations in situations where there are no unchanging 
referents. When nothing is stable-no clear fixed points or undisputed guiding principles exist-leaders are left with nothing by which to steer. It becomes impossible to tell up from down or progress from regress. When nothing is stable-i.e., an absence of fixed points, dependable principles, or stable benchmarks-leaders tend to make up their own rules (Weick and Sutcliffe 2001; Weick 1993). They make sense of the ambiguity and chaos they experience by deciding for themselves what is real and what is appropriate based on criteria such as past experience, immediate payoff, personal reward, and so on (March 1994).

In the ethical arena, it has become clear that in highpressure, high-velocity environments, some leaders have simply made up their own rules. They ended up cheating, lying, waffling, or claiming naiveté, not only because it was to their economic advantage, but because they had created their own rationale for what was acceptable. They operated in rapidly evolving, complex, and high-pressure environments where rules and conditions change constantly. Although their actions are now judged to be unethical and harmful to others, within the rationale they had created for themselves, and within their socially constructed context, those actions made perfect sense to themselves at the time (Mitchell 2001). This is why rules and standards meant to guide what is right and wrong, appropriate and inappropriate, legal and illegal have escalated in the interest of identifying fixed points (e.g., Sarbanes-Oxley).

The problem is, standards that avoid harm or control wrongdoing are not the same as standards that lead to one that is the best. Avoiding the bad is not the same as pursuing the good. Rules and standards that initially appear to guide ethical obligations and socially responsible action may actually lead to the reverse. For example, unions often "work to rule" - doing only what is specified in contracts and rules - as a substitute for going on strike. This pattern of behavior quickly destroys normal organizational functioning. Similarly, following the letter of the law in accounting practices, environmental pollution standards, or performance appraisal systems often leads to the opposite of the intended outcome-e.g., recalcitrance, rigidity, resistance, and rebellion (Caza and Cameron 2008).

More importantly, ethical standards often change over time and circumstance. Ethical standards regarding segregation in public schools, for example, have changed markedly between the 1960s and the present time. The same can be said for ethics associated with financial transactions, accounting principles, environmental policies, sustainability, death, marriage, free speech, and many others. Ethical standards frequently do not remain stable because they are socially constructed. Hence, ethics may serve as inadequate fixed points and may not always identify universalistic standards across different contexts.
Rules meant to specify duty or control behavior may be inadequate standards because they change (thus, disqualifying them as fixed points) and do not always lead to desirable outcomes (Caza et al. 2004).

On the other hand, virtuousness can serve as a fixed point to guide leadership in times of ambiguity, turbulence, and high velocity change. This is because virtuousness represents what people aspire to be at their best_-goodness and nobility - and these aspirations are universal and unchanging in essentially all societies, cultures, and religions (Peterson and Seligman 2004; Kidder 1994). Without virtuousness, it is difficult to identify unchanging fixed points by which to manage change. Thus, responsible leadership, as represented by virtuousness, is leadership that can effectively manage the turbulence and instability characterizing the current external environment. Virtuousness represents the unchanging standard by which to make decisions.

\section{Virtuousness and Positive Organizational Outcomes}

Despite the fact that virtuousness need not be associated with instrumental outcomes to be of worth, an extensive amount of evidence has been produced showing that virtuous behavior is associated with desirable outcomes. For example, honesty, transcendent meaning, caring and giving behavior, gratitude, hope, empathy, love, and forgiveness, among other virtues, have been found to predict desired outcomes, such as individuals' commitment, satisfaction, motivation, positive emotions, effort, physical health, and psychological health (Andersson et al. 2007; Giacalone et al. 2005; Fry et al. 2005; Kellett et al. 2006; Gittell et al. 2006; Luthans et al. 2007; Dutton and colleagues 2006; Grant 2007; Cameron and Caza 2004; Snyder 1994; Sternberg 1998; Seligman 2002; Peterson and Bossio 1991; Harker and Keltner 2001; McCullough et al. 2000; Emmons 1999). While relatively few studies have investigated virtuousness in the leadership of organizations, a limited number of investigations have explored the effects of virtuous leadership on organizational performance.

For example, Cameron and Caza (2002) and Cameron et al. (2004) conducted a series of studies in which indicators of virtuousness and of performance outcomes were assessed in organizations across sixteen industries (e.g., retail, automotive, consulting, health care, manufacturing, financial services, not-for-profit). All organizations in these studies had recently downsized, so that the well-documented negative effects associated with downsizing were likely to accrue. That is, downsizing almost always produces deteriorating performance. Most organizations regress in productivity, quality, morale, trust, and customer satisfaction after downsizing (Cameron 1994, 1998; Cascio et al. 1997). 
Leadership virtuousness scores in each organization were measured by means of a survey instrument assessing compassion, integrity, forgiveness, trust, and optimism in the organization's leadership (concepts included on lists of universally valued virtues, e.g., Chun 2005; Peterson and Seligman 2004). Organizational performance outcomes consisted of objective measures of profitability, productivity, quality, customer retention, and employee retention (voluntary turnover) from company records, as well as employee ratings of similar outcomes. Statistically significance relationships were found between virtuousness scores and both objective and perceived measures of performance outcomes. Organizations with higher virtuousness scores had significantly higher productivity, quality, customer retention, and lower employee turnover than other organizations. When controlling for factors, such as size, industry, and amount of downsizing, organizations scoring higher in virtuousness were significantly more profitable, and, when compared to competitors, industry averages, stated goals, and past performance, they also achieved significantly higher performance on the other outcome measures as well.

In a more refined study, Bright et al. (2006) investigated tonic virtuousness-or virtuousness that occurs irrespective of conditions, such as kindness or integrity - and phasic virtuousness-or virtuousness that is dependent on circumstances, such as forgiveness when harm is done or courage when danger is present-in relation to organizational resilience. When leaders demonstrated virtuousness in the midst of downsizing, their organizations were significantly more able to absorb system shocks, to bounce back from difficulties, to heal relationships, and to collaborate. When organizations had virtuous leaders-both tonically and phasically - they were also more proficient at carrying on effectively despite the setbacks associated with downsizing.

A different kind of study was conducted in the U.S. airline industry after the tragedy of September 11, 2001. This study investigated the relationships between the virtuousness of the downsizing strategies implemented by leaders and the financial return achieved by the organizations (Gittell et al. 2006). The tragedy led to enormous financial losses for the U.S. airline companies, and the study examined the extent to which the leaders of these firms approached financial setbacks in virtuous ways. Virtuousness in this study was defined as preserving human dignity, investing in human capital, and providing an environment in which employee well-being was a priority. Eight of ten U.S. airline companies downsized, but leaders differed markedly in the ways that downsizing was approached.

Controlling for unionization, fuel price hedging, and financial reserves, the study found that the correlation between the virtuousness of the downsizing strategy and financial return (as measured by stock price gains) was $p=0.86$ in the first 12 months and $p=0.79$ over the next 5 years. The company with the highest level of leadership virtuousness earned the highest level of financial return in the industry. Virtuousness and financial return were positively and significantly related over the next 5 years.

Two additional studies specifically investigated the extent to which leadership virtuousness produces these performance improvements rather than having higher performance lead to virtuousness on the part of leaders (Cameron et al. 2011). One study examined 40 financial service organizations, and the other examined 30 health care organizations over multiple years to discover what happened to performance when virtuousness scores increased or decreased. These studies investigated the extent to which leaders fostered and enabled virtuous practices and promoted a culture characterized by virtuousness. Virtuousness was measured by six dimensions: caring (people care for, are interested in, and maintain responsibility for one another as friends), compassionate support (people provide support for one another including kindness and compassion when others are struggling), forgiveness (people avoid blaming and forgive mistakes), inspiration (people inspire one another at work), meaning (the meaningfulness of the work is emphasized, and people are elevated and renewed by their work), and respect, integrity, and gratitude (people treat one another with respect and express appreciation for one another as well as trusting one another and maintaining integrity). ${ }^{3}$

At the beginning of the study period, leaders of these financial services organizations had embarked on systematic efforts to incorporate virtuous practices into their corporate cultures. The performance outcomes of interest were employee turnover, organizational climate, and six financial performance measures, all of which were obtained

\footnotetext{
3 These six dimensions of virtuousness were empirically derived from an assessment of 114 indicators of virtuousness. They are very similar to a proposed comprehensive list of virtues reported in prior published literature. Specifically, in one of the few published listings of proposed virtuous practices in organizations, Chun (2005) reviewed several previous inventories of virtues and analyzed the corporate ethical value statements of 158 Fortune Global firms. Her analyses produced six dimensions of virtuous practices. Her six dimensions incorporated lists of individual virtues proposed by Aristotle, Solomon (1999), Murphy (1999), Moberg (1999), and Shanahan and Hyman (2003). Each of Chun's six dimensions is incorporated within the 6 positive practice dimensions that emerged in these studies. Specifically, Chun's "integrity" is assessed as "respect, integrity, and gratitude" in this study. Chun's "empathy" is assessed as "compassionate support" in this study. Chun's "warmth" is assessed as "caring" in this study. Chun's "courage" has similar items as "meaning" in this study. Chun's "conscientiousness" has similar items as "forgiveness" in this study. And Chun's "zeal" is assessed as "inspiration" in this study.
} 
from company records. Organizations that achieved higher levels of aggregated virtuousness scores also produced significantly higher financial performance, lower employee turnover, and better overall organizational climate 1 year later than did those organizations with lower virtuousness scores. Organizations that became highly virtuous generated better results in the following year than comparison organizations. This suggests that leadership virtuousness was predicting financial results rather than the reverse.

The second study conducted among 30 health care organizations also investigated changes in virtuousness scores over time and their effects on certain indicators of organizational performance. Leaders of these organizations had engaged in multi-day sessions designed to help them implement and facilitate virtuous practices and processes in their organizations. Two findings of interest emerged from this study. One is that when comparing organizations that attempted to improve in virtuousness compared to those that did not, organizations whose leaders were exposed to virtuousness training improved their virtuous practice scores significantly over a 3 year period. Units not exposed to virtuousness training did not improve.

A second finding is that organizations which improved the most in their virtuousness scores also produced the most improvement in the outcomes. Double digit improvement was detected over the 2 year period on the outcome measures included in the study. Organizations that improved in overall virtuousness outperformed organizations that did not improve in subsequent years in patient satisfaction, turnover, climate, resource adequacy, and quality of care.

The irony in this research is that while virtuousness does not require a visible, instrumental pay-off to be of worth, if observable, bottom-line impacts are not detected, then attention to virtuousness usually becomes subservient to the very real pressures related to enhancing financial return and organizational value (Jenson 2002; Davis 2008). Few business leaders invest in practices or processes that do not produce higher returns to shareholders, profitability, productivity, and customer satisfaction. Without visible payoff, in other words, those with stewardship for organizational resources ignore virtuousness and consider it of little relevance to important stakeholders. Hence, when associations between virtuousness and desired outcomes are observed in organizations, leaders may be more likely to respond to its pragmatic utility. Enhancing virtuousness also enhances economic outcomes.

\section{Conclusion}

Associating responsibility with virtuousness provides two advantages. One is that it helps identify a universally accepted standard for what leaders can consider the best or good for individuals and their organizations. Virtuousness represents the best of what humankind aspires to achieve, and responsible leadership in pursuit of the highest good is a worthy aspiration.

Second, evidence suggests that virtuous leadership produces desirable ends. These ends can provide advantages for all constituencies-rather than benefiting some at the expense of others-by focusing on virtuous outcomes. For example, Seligman (2011) recently articulated a goal for the field of psychology to be achieved by the year 2051 . This goal is to have $51 \%$ of the world's population flourishing by that date. Flourishing is defined as having people experience positive emotions, experience engagement (flow), experience satisfying relationships, experience meaningfulness in their activities, and experience achievement. These indicators were selected because they are argued to represent universally valued outcomes for all human beings. In the terms of this article, they represent potentially virtuous objectives. Huppert et al. (2009) found that the highest levels of flourishing are currently in Northern Europe (e.g., Denmark, Norway) at approximately $35 \%$, whereas the lowest levels of flourishing are in Eastern Europe (e.g., Russia and Bulgaria) at approximately $5 \%$. Adopting an approach to responsible leadership that includes the connotation of virtuousness would seem to be one of the most likely mechanisms for making progress toward such an aspiration.

Taking responsibility as a leader, in other words, certainly involves accountability, dependability, authority, and empowerment. If responsibility also includes the notion of virtuousness, however, the implications then become much more far-reaching and inclusive. Responsibility implies the pursuit of the ultimate best-eudaemonism-and, secondarily, to produce advantages for constituencies who may never be affected otherwise.

Open Access This article is distributed under the terms of the Creative Commons Attribution Noncommercial License which permits any noncommercial use, distribution, and reproduction in any medium, provided the original author(s) and source are credited.

\section{References}

Algoe, S. B., \& Haight, J. (2009). Witnessing excellence in action: The other-praising emotions of elevation, gratitude, and admiration. Journal of Positive Psychology, 4, 105-127.

Alzola, M. (2008). Character and environment: The status of virtues in organizations. Journal of Business Ethics, 78, 343-357.

Andersson, L. M., Giacalone, R. A., \& Jurkiewicz, C. L. (2007). On the relationship of hope and gratitude to corporate social responsibility. Journal of Business Ethics, 70, 401-409.

Aquinas, T. (1984). Treatise on the virtues (J. A. Oesterle, Trans.). Notre Dame, IN: University of Notre Dame Press.

Aristotle. (1999). Nicomachean ethics (M. Oswald, Trans.). Upper Saddle River NJ: Prentice Hall. 
Aristotle: Metaphysics XII 7, 3-4.

Asche, S. E. (1952). Social psychology. Englewood Cliffs, NJ: Prentice Hall.

Barge, J. K., \& Oliver, C. (2003). Working with appreciation in managerial practice. Academy of Management Review, 28, 124-142.

Bass, B. M., \& Bass, R. (2008). The bass handbook of leadership: Theory, research, and managerial applications (4th ed.). New York: Free Press.

Batson, C. D., Klein, T. R., Highberger, L., \& Shaw, L. S. (1995). Immorality from empathy-induced altruism: When compassion and justice conflict. Journal of Personality and Social Psychology, 68, 1042-1054.

Bollier, D. (1996). Aiming higher: 25 Stories of how companies prosper by combining sound management and social vision. New York: Amacom.

Bright, D. S., Cameron, K. S., \& Caza, A. (2006). The amplifying and buffering effects of virtuousness in downsized organizations. Journal of Business Ethics, 64, 249-269.

Brown, M. E., \& Trevino, L. S. (2006). Ethical leadership: A review and future directions. Leadership Quarterly, 17, 595-616.

Cameron, K. S. (1994). Strategies for successful organizational downsizing. Human Resource Management Journal, 33, 89-112.

Cameron, K. S. (1998). Strategic organizational downsizing: An extreme case. Research in Organizational Behavior, 20, $185-229$.

Cameron, K. S. (2006). Good or not bad: Standards and ethics in managing change. Academy of Management Learning and Education Journal, 4, 317-323.

Cameron, K. S. (2008). Paradox in positive organizational change. Journal of Applied Behavioral Science, 44, 7-24.

Cameron, K. S. (2010). Five keys to flourishing in trying times. Leader to Leader, 55, 45-51.

Cameron, K. S., Bright, D., \& Caza, A. (2004). Exploring the relationships between organizational virtuousness and performance. American Behavioral Scientist, 4, 766-790.

Cameron, K. S., \& Caza, A. (2002). Organizational and leadership virtues and the role of forgiveness. Journal of Leadership and Organizational Studies, 9, 33-48.

Cameron, K. S., \& Caza, A. (2004). Contributions to the discipline of positive organizational scholarship. American Behavioral Scientist, 47, 731-739.

Cameron, K. S., Dutton, J. E., \& Quinn, R. E. (2003). Positive organizational scholarship. San Francisco: Berrett-Kohler.

Cameron, K. S., \& Lavine, M. (2006). Making the impossible possible: Leading extraordinary performance-the rocky flats story. San Francisco: Berrett-Koehler.

Cameron, K. S., Mora, C., Leutscher, T., \& Calarco, M. (2011). Effects of positive practices on organizational effectiveness. The Journal of Applied Behavioral Science, 20, 1-43.

Cameron, K. S., \& Winn, B. (2012). Virtuousness in organizations. In K. S. Cameron \& G. M. Spreitzer (Eds.), Oxford handbook of positive organizational scholarship. New York: Oxford University Press.

Cascio, W. F., Young, C. E., \& Morris, J. R. (1997). Financial consequences of employment change decisions in major U.S. corporations. Academy of Management Journal, 40, 1175-1189.

Cawley, M. J., Martin, J. E., \& Johnson, J. A. (2000). A virtues approach to personality. Personality and Individual Differences, 28, 997-1013.

Caza, A., Barker, B. A., \& Cameron, K. S. (2004). Ethics and ethos: The buffering and amplifying effects of ethical behavior and virtuousness. Journal of Business Ethics, 52, 169-178.

Caza, A., \& Cameron, K. S. (2008). Positive organizational scholarship: What does it achieve? In C. Cooper \& S. Clegg (Eds.), Handbook of macro-organizational behavior. New York: Sage.
Caza, A., \& Carroll, B. (2012). Critical studies and positive organizational scholarship. In K. S. Cameron \& G. M. Spreitzer (Eds.), Oxford handbook of positive organizational scholarship. New York: Oxford University Press.

Chapman, J. W., \& Galston, W. A. (1992). Virtue. New York: New York University Press.

Chun, R. (2005). Ethical character and virtue of organizations: An empirical assessment and strategic implications. Journal of Business Ethics, 57, 269-284.

Cialdini, R. B. (2000). Influence: The science of persuasion. New York: Allyn Bacon.

Comte-Sponville, A. (2001). A small treatise of the great virtues (C. Temerson, Trans.). New York: Metropolitan Books.

D'Amato, M. R., \& Jagoda, H. (1962). Effect of early exposure to photic stimulation on brightness discrimination and exploratory behavior. Journal of Genetic Psychology, 101, 267-271.

Davis, G. F. (2008). The rise and fall of finance and the end of the society of organizations. Academy of Management Perspectives, 23, 27-44.

Den Hartog, D. N., \& De Hoogh, A. H. B. (2009). Empowering behavior and leader effectiveness and integrity: Studying perceptions of ethical leader behavior from a levels-of-analysis perspective. European Journal of Work and Organizational Psychology, 18, 199-230.

Dent, N. (1984). The moral psychology of the virtues. New York: Cambridge University Press.

Doh, J. P., \& Stumph, S. (2005). Handbook on responsible leadership and governance in global business. New York: Oxford University Press.

Dutton, J. E., \& Heaphy, E. (2003). The power of high-quality connections. In K. S. Cameron, J. E. Dutton, \& R. E. Quinn (Eds.), Positive organizational scholarship. San Francisco: Berrett Koehler.

Dutton, J. E., \& Sonenshein, S. (2007). Positive organizational scholarship. In S. Lopez \& A. Beauchamps (Eds.), Encyclopedia of positive psychology. Malden, MA: Blackwell Publishing.

Dutton, J. E., Worline, M. C., Frost, P. J., \& Lilius, J. M. (2006). Explaining compassion organizing. Administrative Science Quarterly, 51, 59-96.

Eisenberg, N. (1986). Altruistic emotion, cognition, and behavior. Hillsdale, NJ: Erlbaum.

Emmons, R. A. (1999). The psychology of ultimate concerns: Motivation and spirituality in personality. New York: Guilford Press.

Erhard-Seibold, E. V. (1937). The heliotrope tradition. Orisis, 3, 22-46.

Ewin, R. E. (1995). The virtues appropriate for business. Business Ethics Quarterly, 5, 833-842.

Fineman, S. (2006). On being positive: Concerns and counterpoints. Academy of Management Review, 31, 270-291.

Fowers, B. J. (2005). Virtue and psychology: Pursuing excellence in ordinary practice. Washington DC: APA Press.

Fowers, B. J. (2008). From continence to virtue. Theory and Psychology, 18, 629-653.

Fowers, B. J. (2009). Virtue. In S. J. Lopez (Ed.), The encyclopedia of positive psychology. West Sussex, UK: Blackwell.

Fredrickson, B. L. (2003). Positive emotions and upward spirals in organizations. In K. S. Cameron, J. E. Dutton, \& R. E. Quinn (Eds.), Positive organizational scholarship: Foundations of a new discipline. San Francisco: Berrett-Koehler.

Fredrickson, B. L. (2009). Positivity. New York: Crown.

Fredrickson, B. L., \& Joiner, T. (2002). Positive emotions trigger upward spirals toward emotional well-being. American Psychologist, 13, 172-175.

Fry, L. W., Keim, G. D., \& Meiners, R. E. (1982). Corporate contributions: Altruistic of for-profit? Academy of Management Journal, 25, 94-106. 
Fry, L. W., Vitucci, S., \& Cedillo, M. (2005). Spiritual leadership and army transformation: Theory, measurement, and establishing a baseline. Leadership Quarterly, 16, 835-862.

George, J. M. (1995). Leader positive mood and group performance: The case of customer service. Journal of Applied Social Psychology, 25, 778-794.

Gergen, K. J. (1999). An invitation to social constructionism. London: Sage.

Giacalone, R. A., Paul, K., \& Jurkiewicz, C. L. (2005). A preliminary investigation into the role of positive psychology in consumer sensitivity to corporate social performance. Journal of Business Ethics, 58, 295-305.

Gittell, J. H., Cameron, K. S., Lim, S., \& Rivas, V. (2006). Relationships, layoffs, and organizational resilience. Journal of Applied Behavioral Science, 42, 300-328.

Grant, A. M. (2007). Relational job design and the motivation to make a prosocial difference. Academy of Management Review, 32, 393-417.

Grant, A. M., \& Schwartz, B. (2011). Too much of a good thing: The challenges and opportunity of the inverted-U. Perspectives in Psychological Science, 6, 61-76.

Haight, J. (2006). The happiness hypothesis: Finding modern truth in ancient wisdom. New York: Basic Books.

Handelsman, M. M., Knapp, S., \& Gottlieb, M. C. (2002). Positive ethics. In C. R. Snyder \& S. J. Lopez (Eds.), Handbook of positive psychology. New York: Oxford.

Harker, L. A., \& Keltner, D. (2001). Expressions of positive emotion in women's college yearbook pictures and their relationship to personality and life outcomes across adulthood. Journal of Personality and Social Psychology, 80, 112-124.

Hatch, M. J. (1999). Exploring the empty spaces of organizing: How improvisational jazz helps redescribe organizational structure. Organizational Studies, 20, 75-100.

Hauser, M. (2006). Moral minds: How nature designed our universal sense of right and wrong. New York: ECCO.

Hoffman, A. J., \& Haigh, N. (2012). Parallels between sustainability and positive organizational scholarship. In K. S. Cameron \& G. M. Spreitzer (Eds.), Oxford handbook of positive organizational scholarship. New York: Oxford University Press.

Huppert, F. A., Marks, N., Clark, A., Siegrist, J., Stutzer, A., Vitterso, J., et al. (2009). Measuring well-being across Europe: description of the ESS well-being module and preliminary findings. Social Indicators Research, 92(3), 301-315.

Jenson, M. C. (2002). Value maximization, stakeholder theory and the corporate objective function. Business Ethics Quarterly, 12, $235-256$.

Kellett, J. B., Humphrey, R. H., \& Sleeth, R. G. (2006). Empathy and the emergence of task and relations leaders. Leadership Quarterly, 17, 146-162.

Kidder, R. M. (1994). Shared values for a troubled world. San Francisco: Jossey Bass.

Krebs, D. (1987). The challenge of altruism in biology and psychology. In C. Crawford, M. Smith, \& D. Krebs (Eds.), Sociobiology and psychology. Hillsdale, NJ: Lawrence Erlbaum.

Leavitt, H. J. (1996). The old days, hot groups, and managers' lib. Administrative Science Quarterly, 41, 288-300.

Luthans, F., Avolio, B., Avey, J. B., \& Norman, S. M. (2007). Psychological capital: Measurement and relationship with performance and satisfaction. Personnel Psychology, 60, 541-572.

Maak, T., \& Pless, N. M. (2006a). Responsible leadership. London: Routledge.

Maak, T., \& Pless, N. M. (2006b). Responsible leadership in a stakeholder society-a relational perspective. Journal of Business Ethics, 66, 99-115.

MacIntyre, A. (1984). After virtue: A study in moral theory (2nd ed.). Notre Dame, IN: University of Notre Dame Press.
March, J. G. (1994). A primer on decision making: How decisions happen. New York: Free Press.

Maslow, A. (1971). The farthest reaches of human nature. New York: Viking.

McCullough, M. E., Pargament, K. I., \& Thoreson, C. (2000). Forgiveness: Theory, research, and practice. New York: Guilford.

Meindl, J. R., \& Ehrlich, S. B. (1987). The romance of leadership and the evaluation of organizational performance. Academy of Management Journal, 30, 91-109.

Miller, G. F. (2007). Sexual selection for moral virtues. The Quarterly Review of Biology, 82, 97-125.

Mitchell, L. E. (2001). Corporate irresponsibility: America's newest export. New Haven, CT: Yale University Press.

Moberg, D. J. (1999). The big five and organizational virtue. Business Ethics Quarterly, 9, 245-272.

Moore, G., \& Beadle, R. (2006). In search of organizational virtue in business: Agents, goods, practices, institutions, and environments. Organization Studies, 27, 369-389.

Moore, C., \& Richardson, J. J. (1988). The politics and practice of corporate responsibility is Great Britain. Research in Corporate Social Performance and Policy, 10, 267-290.

Mrosovsky, N., \& Kingsmill, S. F. (1985). How turtles find the sea. Zeitschrift Fur Tierpsychologie-Journal of Comparative Ethology, 67, 237-256.

Murphy, P. E. (1999). Character and virtue ethics in international marketing: An agenda for managers, researchers, and educators. Journal of Business Ethics, 18, 107-124.

Nielsen, R. (2006). Introduction to the special issue-in search of organizational virtue: Moral agency in organizations. Organization Studies, 27, 318-321.

Orlikowski, W. J. (2000). Using technology and constituting structures: A practice lens for studying technology in organizations. Organization Science, 11(4), 404-428.

Peterson, C., \& Bossio, L. M. (1991). Health and optimism. New York: Free Press.

Peterson, C., \& Seligman, M. E. P. (2004). Character strengths and virtues. New York: Oxford University Press.

Piliavin, J. A., \& Charng, H. (1990). Altruism: A review of recent theory and research. Annual Review of Sociology, 16, $27-65$.

Pinker, S. (1997). How the mind works. New York: W.W. Norton.

Pless, N. M. (2007). Understanding responsible leadership: Role identity and motivational drivers. Journal of Business Ethics, 74 , 437-456.

Rachels, J. (1999). The elements of moral philosophy. New York: McGraw-Hill.

Rawls, J. (1971). A theory of justice. Cambridge, MA: Harvard University Press.

Rego, A., Ribeiro, N., \& Cunha, M. (2010). Perceptions of organizational virtuousness and happiness as predictors of organizational citizenship behaviors. Journal of Business Ethics, 93, 215-235.

Salancik, G. R., \& Meindl, J. R. (1984). Corporate attributions as strategic illusions of management control. Administrative Science Quarterly, 29, 238-254.

Sánchez, C. M. (2000). Motives for corporate philanthropy in El Salvador: Altruism and political legitimacy. Journal of Business Ethics, 27, 363-375.

Schimmel, S. (1997). The seven deadly sins: Jewish, Christian, and classical reflections on human nature. New York: The Free Press.

Seligman, M. E. P. (2002). Authentic happiness. New York: Free Press.

Seligman, M. E. P. (2011). Flourish: A visionary new understanding of happiness and well-being. New York: Free Press. 
Sethi, R., \& Nicholson, C. Y. (2001). Structural and contextual correlates of charged behavior in product development teams. Journal of Product Innovation Management, 18, 154-168.

Shanahan, K. J., \& Hyman, M. R. (2003). The development of a virtue ethics scale. Journal of Business Ethics, 42, 197-208.

Sison, A. J. G. (2006). Leadership, character, and virtues from an Aristotelian viewpoint. In T. Maak \& N. M. Pless (Eds.), Responsible leadership. London: Routledge.

Smith, J. C., \& Baker, H. D. (1960). Conditioning in the horseshoe crab. Journal of Comparative and Physiological Psychology, 53, 279-281.

Snyder, C. R. (1994). The psychology of hope. New York: Free Press.

Solomon, R. C. ( 1999). A better way to think about business. New York: Oxford University Press.

Spreitzer, G. (2007). Participative organizational leadership, empowerment, and sustainable peace. Journal of Organizational Behavior, 28, 1077-1096.

Spreitzer, G. M., De Janesz, S., \& Quinn, R. E. (1999). Empowered to lead: The role of psychological empowerment in leadership. Journal of Organizational Behavior, 20(4), 511-526.

Sternberg, J. J. (1998). A balanced theory of wisdom. Review of General Psychology, 2, 347-365.

Tangney, J. P., Stuewig, J., \& Mashek, D. J. (2007). Moral emotions and moral behavior. Annual Review of Psychology, 58, 345-372.

Trevino, L. K., Brown, M. E., \& Hartman, L. P. (2003). A qualitative investigation of perceived ethical leadership: Perceptions from inside and outside the executive suite. Human Relations, 55, 5-37.
Walsh, J. P. (1999). Business must talk about its social role. In T. Dickson (Ed.), Mastering strategy. London: Financial Times/ Prentice Hall.

Walsh, J. P., Weber, K., \& Margolis, J. D. (2003). Social issues and management: Our lost cause found. Journal of Management, 29, $859-881$.

Weaver, G. R. (2006). Virtue in organizations: Moral identity as a foundation for moral agency. Organization Studies, 27, 341-368.

Weick, K. E. (1993). The collapse of sensemaking in organizations: The Mann Gulch disaster. Administrative Science Quarterly, 38, 628-652.

Weick, K. E., \& Sutcliffe, K. M. (2001). Managing the unexpected: Assuring high performance in an age of complexity. San Francisco: Jossey-Bass.

Weiner, N. O. (1993). The harmony of the soul: Mental health and moral virtue reconsidered. Albany, NY: State University of New York Press.

Whetstone, T. J. (2003). The language of managerial excellence: Virtues as understood and applied. Journal of Business Ethics, 44, 343-357.

Wright, T. A., \& Goodstein, J. (2007). Character is not dead in management research: A review of individual character and organization-level virtue. Journal of Management, 33, 928-948.

Yukl, G., Gordon, A., \& Taber, T. (2002). A hierarchical taxonomy of leadership behavior: Integrating a half century of behavior research. Journal of Leadership \& Organizational Studies, 9, $15-32$. 